\title{
Combination of Neoadjuvant Therapy and Liver Transplantation in Pediatric Multisystem Langerhans Cell Histiocytosis With Liver Involvement
}

\author{
Chen Chen, Guangxiang Gu*, Tao Zhou, Mingzhu Huang and Qiang Xia* \\ Department of Liver Surgery and Liver Transplantation Center, Renii Hospital, Affiliated to Shanghai Jiao Tong University \\ School of Medicine, Shanghai, China
}

Background: Langerhans cell histiocytosis $(\mathrm{LCH})$ is characterized by misguided myeloid differentiation, whose prognosis was poor with involvement of risk organs. Remaining issues include how to improve the outcomes of patients with risk-organ involvement.

OPEN ACCESS

Edited by:

Jun Li,

University Medical Center Hamburg-Eppendorf, Germany

Reviewed by:

Zofia Helias,

Assistance Publique Hopitaux De

Paris, France

Itziar Astigarraga,

Hospital Universitario Cruces., Spain

*Correspondence:

Guangxiang Gu

guguangxiang@163.com

Qiang Xia

xiaqiang@medmail.com.cn

Specialty section: This article was submitted to

Surgical Oncology,

a section of the journal

Frontiers in Oncology

Received: 29 May 2020 Accepted: 08 September 2020

Published: 07 October 2020

Citation:

Chen C, Gu G, Zhou T, Huang M and Xia Q (2020) Combination of

Neoadjuvant Therapy and Liver

Transplantation in Pediatric

Multisystem Langerhans Cell Histiocytosis With Liver Involvement.

Front. Oncol. 10:566987.

doi: 10.3389/fonc.2020.566987
Methods: A retrospective study was conducted in Renji Hospital exploring the effects of neoadjuvant therapy in combination with pediatric liver transplantation (LT) for LCH patients based on data collected between October 2006 and October 2019.

Results: We presented here five cases of multisystem $\mathrm{LCH}$ patients underwent systemic chemotherapy to control active lesions, followed by LT to treat end-stage liver diseases. Manifestations before LT included elevated transaminase levels ( $n=5,100 \%)$, jaundice ( $n=4,80 \%)$, ascites $(n=3,60 \%)$, and variceal hemorrhage $(n=1,20 \%)$. Three patients underwent orthotopic liver transplantation (OLT) and two underwent living donor liver transplantation (LDLT). Until December 2019, median follow-up time was 32 months (range, 2-67 months). Liver functions significantly improved compared with pre-operative conditions. One patient had perioperative hepatic artery complications and one patient had a recurrence in the lung. EBV infection occurred in four (80\%) patients and CMV infection occurred in one (20\%). There was one case of drug-induced liver injury diagnosed on biopsy 13 months after LT. None underwent re-transplantation and there were no rejection or portal vein and biliary complications.

Conclusion: Combination of neoadjuvant therapy and LT is an effective paradigm in treatment of multisystem LCH with severe liver dysfunction. With advances in chemotherapy regimen for multisystem LCH and LT surgery, perspectives on prognosis for LCH children are promising.

Keywords: Langerhans cell histiocytosis (LCH), neoadjuvant therapy, liver transplantation, follow-up, multisystem

\section{INTRODUCTION}

Langerhans cell histiocytosis (LCH) is a rare neoplasm of myeloid precursor cells, derived from cells from monocyte, macrophage, and dendritic cell lineages (1-3). The annual incidence of LCH is $\sim 1$ per 200,000 children (4). For patients with liver involvement, the risk of death is three times greater than those without (5). 
Infiltrating the skin, liver, spleen, bone marrow, lung, or other systems, there have been more than 100 subtypes described since the first classification in 1987, with a wide range of presentations (6). Therapeutic strategies to LCH patients were often tailored to individuals according to stratification of high- or low- risk groups $(7,8)$. Liver, spleen, and bone marrow are thought to be the organs most at risk. Multisystem LCH patients show poor prognosis, especially congenital cases (9). Although systemic chemotherapy, the mortality rate of patients exhibiting risk organs remain high at $16-38 \%(10)$.

For LCH patients with liver involvement, portal infiltrations can lead to periportal fibrosis and bile duct destruction, resulting portal hypertension, and cirrhosis (10). However, it is clear that children with multiorgan diseases are contraindicated for LT (11). Treatment for these multisystem LCH patients with endstage liver problems should not be restricted to single method. Limited data on neoadjuvant techniques in combination with pediatric LT have been published since 1990s. Recent years, there still has been no satisfactory outcomes for multisystem childhood LCH patient with liver involvement. Therefore, to determine the effect of combination of neoadjuvant therapy and LT for pediatric multisystem LCH patients, medical records of children with a diagnosis of $\mathrm{LCH}$ in our transplant center were retrospectively reviewed.

\section{PATIENTS AND METHODS}

The retrospective single-center study included all LCH patients who have undergone LT at Renji Hospital, Shanghai Jiao Tong University School of Medicine from October 2006 to October 2019. All operations were approved by review board. Informed consent concerning the permission to collect and use data was obtained from all children's guardians.

Organ involvement was defined as follows: for the liver, alanine transaminase (ALT), aspartate transaminase (AST), and bilirubin increase or albumin decrease or liver biopsy confirmed LCH histology characteristics; for the spleen, splenomegaly indicated by ultrasonography ( $\geq 2 \mathrm{~cm}$ under the costal margin); for the hematopoietic system, the presence of thrombocytopenia or leukopenia in the peripheral blood; for the bone and lungs, findings on computed tomography (CT) scan or biopsy; for the skin, seborrheic dermatitis, or eczematous eruption confirmed by pathology; for the ear, clinical manifestations of external acoustic meatus, or purulent secretion with or without pathology evidence.

The type of transplantation included orthotopic liver transplantation (OLT) and living donor liver transplantation (LDLT). All organ donation and matching were achieved through the China Organ Transplant Response System (COTRS). Living donor evaluation was performed before operation. The determination of segments was based on 3D virtual surgery planning system (IQQA-Liver) and intraoperative findings. The left lobe with middle hepatic vein and the left lateral graft were finally chosen in two patients underwent LDLT, respectively. University of Wisconsin solution was used for organ preservation.
In our transplant center, during LT, take down ligaments around liver first, then dissect the hepatic hilum and divide hepatic arteries, common bile duct. Clamp and divide the portal vein and hepatic veins, then remove the native liver. Surgical procedures of OLT differentiate from LDLT in the way of clamping and anastomosis, with reconstruction of both suprahepatic and infrahepatic inferior vena cava in OLT. While in LDLT, dissect all short hepatic veins into the vena cava and reconstruct suprahepatic vena cava. Reconstruct hepatic vein, portal vein, hepatic artery in turn. Finally, end-to-end anastomosis or choledochojejunostomy was used to reconstruct bile duct.

The principles of follow-up are once a week in the first 3 months after discharge, once per 2 weeks from the fourth to sixth month, once per month at 6 months post-operation and visits to the clinic at any time if anything abnormal should occur.

Non-normally distributed qualitative variables were described by medians with interquartile range. Differences between groups were calculated using the Student $t$-test. All statistical tests were two-sides, and $P<0.05$ was considered significant. Analyses were undertaken using GraphPad Prism 7 (GraphPad, Version 7.0a, California).

\section{RESULTS}

\section{Neoadjuvant Therapy and Characteristics Before LT}

The median age of LCH patients at diagnosis was 15 months (range, 13-28 months) (Table 1). The first symptoms lead to diagnosis of LCH were purulent secretion in ear $(n=2)$, skin rash $(n=2)$, and elevated liver enzymes discovered by accident $(n=1)$. All five patients with multisystem LCH had at least three organs involved, belonging to high-risk patients with involvement of two or more organ systems or one or more high-risk organ systems. Organ involvement included liver $(n$ $=5,100 \%)$, spleen $(n=5,100 \%)$, bone $(n=3,60 \%)$, skin $(n$ $=3,60 \%)$, blood system $(n=2,40 \%)$, ear $(n=2,40 \%)$, lung $(n=1,20 \%)$ (Table 2). Patients received systemic neoadjuvant chemotherapy in different children's hospitals before LT, which consisted of an initial phase and maintenance phase (Table 1). One patient turned to second-line therapy because of poor response to initial regimen at the 6 weeks post-treatment evaluation. After evaluated as non-active in other systems, these five $\mathrm{LCH}$ patients underwent LT at Renji Hospital, accounting for $0.25 \%$ among 2,000 cases of pediatric LT form October 2006 to October 2019. The median age at LT was 53 months (range, 24-81 months) (Table 1). Clinical and laboratory manifestations before LT included elevated transaminase levels $(n=5,100 \%)$, jaundice ( $n=4,80 \%)$, ascites $(n=3,60 \%)$, and variceal hemorrhage $(n=1,20 \%)$.

There were three pediatric donors, donation after circulatory death (DCD), and two living donors. The median age of pediatric organ donors was 4 years (range, 2-6 years) and all of them were male. Both living donors were mothers, aged 36, 27 years, respectively. The blood type combinations were identical in four cases and compatible in one case. 
TABLE 1 | Clinical characteristics and neoadjuvant therapy of children with LCH.

\begin{tabular}{|c|c|c|c|c|c|}
\hline $\begin{array}{l}\text { Patient } \\
\text { number }\end{array}$ & $\begin{array}{l}\text { Age at diagnosis } \\
\text { of LCH (years) }\end{array}$ & Chemotherapy before LT & Indications for LT & $\begin{array}{l}\text { Age at LT } \\
\text { (years) }\end{array}$ & Type of LT \\
\hline 1 & 1.25 & $\begin{array}{l}\text { Initial phase: Pred (4 W, taper 2 W) +VCR (D1 of W1-6) } \\
\text { + Ara-C (D1-4 W 1, 3, 5) } \\
\text { Maintenance phase: Perd (D1-5 Q3W) + VCR (D1 Q3W) } \\
\text { +6-MP (QN) }\end{array}$ & $\begin{array}{l}\text { Portal hypertension (varices, splenomegaly), } \\
\text { liver dysfunction, hypersplenism }\end{array}$ & 6.8 & OLT \\
\hline 2 & 1.75 & $\begin{array}{l}\text { Initial phase: Pred (4W, taper 2W) +VP16 (D1-5, 18, 25, } \\
\text { 32, 39) +VBL (D15, 22, 29, 36) } \\
\text { Maintenance phase: 6-MP (W6-52) + VBL (D1, } \\
\text { W9-42/Q3W) + VP16 (D5, W9-42/Q3W) + MTX (D1, } \\
\text { W9-42/Q3W) + THF (D1, W9-42/Q3W) }\end{array}$ & $\begin{array}{l}\text { Portal hypertension (varices, splenomegaly), } \\
\text { liver dysfunction }\end{array}$ & 4.4 & OLT \\
\hline 3 & 1.25 & $\begin{array}{l}\text { First-line therapy: VCR (D1 of W1-5) +VP16 (D1-3 of } \\
\text { W3, D1 of W4-6) +VDS (QW) } \\
\text { Second-line therapy: Ara-C+ Cladribine a }\end{array}$ & Portal hypertension (varices, splenomegaly) & 4.3 & $\begin{array}{l}\text { LDLT (left lobe } \\
+\mathrm{MHV} \text { ) }\end{array}$ \\
\hline 4 & 2.33 & $\begin{array}{l}\text { Initial phase: Pred + VCR + Ara-C } \\
\text { Maintenance phase: VCR+ Pred + Thymosin } \\
\text { Withdrawal in May, } 2015\end{array}$ & Portal hypertension (variceal hemorrhage) & 6.3 & OLT \\
\hline
\end{tabular}

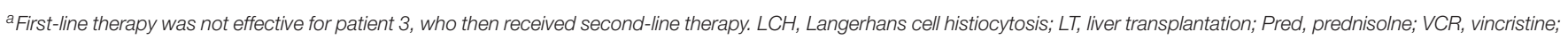

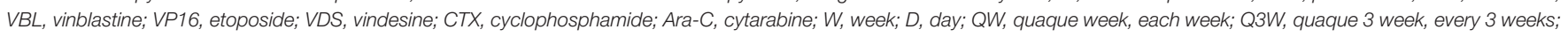
QN, quaque nocte, each night; OLT, orthotopic liver transplantation; LDLT, living donor liver transplantation; MHV, middle hepatic vein; TAC, tacrolimus; MMF, mycophenolate mofetil.

\section{Operative Information}

Three patients underwent whole-liver orthotopic liver transplantation (OLT) using no organs from executed prisoners. Two underwent living donor liver transplantation (LDLT). Of these two grafts, one was a left lateral lobe, one was a left lobe with the middle hepatic vein (MHV). Patients 1 and 5 also underwent splenectomy because of hypersplenism (Figures 1C,D). Graft volume/recipient body weight ratios (GRWR) of the five patients were as follows: $1.43,3.04,1.86,3.47,2.84 \%$. Preoperative computed tomography (CT) scan suggested dilation of intrahepatic bile ducts, space-occupying hepatic lesions, considered hyperplastic nodules or others, splenomegaly, and varicosity (Figures 1A,B), which were confirmed by operation findings. Gross examination revealed greenish-tan liver surface and some appeared micronodular on the external and cut surfaces. Histopathology of the resected liver indicated micronodular cirrhosis with interstitial fibrous proliferation and inflammatory cell infiltration. Immunohistochemistry (IHC) of paraffin-embedded liver samples showed individual CD1a-positive and Langerin-positive cells (Figures 1E,F). No IHC evidence indicated that the gallbladders had Langerhans cell infiltration.

\section{Post-operative Follow-Up}

All five LCH patients have been followed up as of the date of this manuscript, and none underwent re-transplantation. The median follow-up time until December 2019 was 32 months (range 2-67 months). Liver functions returned to normal within 3-4 weeks after LT. According to the most recent follow-up data, liver functions improved significantly compared with preoperative status, reflecting the significant decreases in transaminase levels (Figure 2). The type of operation did not appear to affect long-term prognosis. Immunosuppression was based on tacrolimus (TAC), together with prednisone tapers in the early period post-operation. Three patients continue to take mycophenolate mofetil in combination with TAC and one patient also took rapamycin as a supplement. No patients were administered postoperative chemotherapy. Liver function tended to remain stable over the long term (Figure 3). The surgeries caused transient elevations of transaminase levels compared to pre-operation data, both of which would decrease later. Transaminase levels of patient 2 increased 3 weeks after LT and biopsy indicated moderate liver damage with mild central perivenulitis but no rejection. After reducing the dosage of TAC from $1 \mathrm{mg} / 1.5 \mathrm{mg}$ to finally $0.75 \mathrm{mg} / 0.5 \mathrm{mg}$, ALT and AST levels decreased substantially.

\section{Complications After LT}

The first LCH patient had hepatic artery thrombosis in the early postoperative period. He had signs of soft tissue in the right lung found on PET-CT 7 months after LT that were similar to findings 4 months before LT. No obvious changes of opacities in the lung were found on CT the following year. No others had evidence of recurrence or progressive lesions. This patient had drug-induced liver injury 13 months after LT. For all five patients, no portal vein complications and biliary complications occurred. None of patients developed post-transplant lymphoproliferative disorder; however, four children had Epstein-Barr virus (EBV) infection after LT, with EBV-DNA load in venous blood exceeding 5 $\times 10^{3}$ copies $/ \mathrm{ml}$. One patient had cytomegalovirus (CMV) infection, with CMV-DNA load in venous blood more than 500 copies $/ \mathrm{ml}$. None were infected with hepatitis B virus. None had pathological diagnoses of acute rejection (Table 3). Two patients who underwent splenectomy had increased platelet 
TABLE 2 | Organs and systems involvements of LCH patients: manifestations and pre-operation imaging examinations.

\begin{tabular}{|c|c|c|c|c|c|c|c|}
\hline $\begin{array}{l}\text { Patient } \\
\text { number }\end{array}$ & $\begin{array}{l}\text { Involved organs/ } \\
\text { systems }\end{array}$ & Liver & Spleen & Blood system & Bone & Skin & Others \\
\hline 1 & $\begin{array}{l}\text { Liver, spleen, blood } \\
\text { system, lung, neoplasm of } \\
\text { external acoustic meatus }\end{array}$ & $\begin{array}{l}\text { Liver dysfunction: ALT } \\
104.9 \text { U/L, AST } 172.8 \\
\text { U/L, TB } 78.5 \text { umol/L }\end{array}$ & Splenomegaly & $\begin{array}{l}\text { WBC } 3.6 \times 10^{\wedge} 9 / \mathrm{L} \\
\text { PLT } 62 \times 10^{\wedge} 9 / \mathrm{L}\end{array}$ & None & $\begin{array}{l}\text { Negative by } \\
\text { immunohistochemistry }\end{array}$ & $\begin{array}{l}\text { Lymph node biopsy } \\
\text { through thoracoscopy } \\
\text { and neoplasm of } \\
\text { external acoustic canal } \\
\text { showed features } \\
\text { consistent with LCH }\end{array}$ \\
\hline 2 & Liver, spleen, bone & $\begin{array}{l}\text { Liver dysfunction: ALT } 79 \\
\text { U/L, AST } 178 \text { U/L, TB } 457 \\
\text { umol/L }\end{array}$ & Splenomegaly & None & $\begin{array}{l}\text { Left temporal skull lesions } \\
\text { immunohistochemistry indicated } \\
\text { Langerin }(+++), \text { S-100(+++), } \\
\text { CD1a }(+++), \text { Kp-1(-), Ki67:20\% } \\
\text { (proliferation index) }\end{array}$ & None & None \\
\hline 3 & Liver, spleen, skin, bone & $\begin{array}{l}\text { Liver dysfunction: ALT } 38 \\
\text { U/L, AST } 110 \text { U/L, TB } 43 \\
\text { umol/L }\end{array}$ & Splenomegaly & None & $\begin{array}{l}\text { Right distal femur, left ilium, left } \\
\text { occipital bone, frontal bone small } \\
\text { low-density lesions }\end{array}$ & $\begin{array}{l}\text { Skin of back } \\
\text { immunohistochemistry: } \\
\text { CD1a+, S100+, Langerin+, } \\
\text { PGM1-, MAC387 partial +, } \\
\text { CK-, LCA+, MPO- }\end{array}$ & None \\
\hline 4 & Liver, spleen, skin, bone & $\begin{array}{l}\text { Liver dysfunction: ALT } 31 \\
\text { U/L, AST } 131 \mathrm{U} / \mathrm{L}, \mathrm{TB} \\
12.8 \mathrm{umol} / \mathrm{L}\end{array}$ & Splenomegaly & None & $\begin{array}{l}\text { Right parietal bone, frontal bone, left } \\
\text { temporal bone and occipital bone } \\
\text { multiple bone defects }\end{array}$ & Skin of back confirmed LCH & None \\
\hline 5 & $\begin{array}{l}\text { Liver, spleen, blood } \\
\text { system, Skin, Ear }\end{array}$ & $\begin{array}{l}\text { Liver dysfunction: ALT } 159 \\
\text { U/L, AST } 198 \text { U/L, TB } \\
172.2 \text { umol/L }\end{array}$ & Splenomegaly & WBC $2.06 \times 10^{\wedge} 9 / L$ & None & $\begin{array}{l}\text { Immunohistochemistry: } \\
\text { S100-, CD163+, CD1a+, } \\
\text { Ki67 about 30\%, INI1+, } \\
\text { CK-, EMA-, LCA+ }\end{array}$ & $\begin{array}{l}\text { Ear pus, but no } \\
\text { neoplasm and no } \\
\text { pathological evidence }\end{array}$ \\
\hline
\end{tabular}




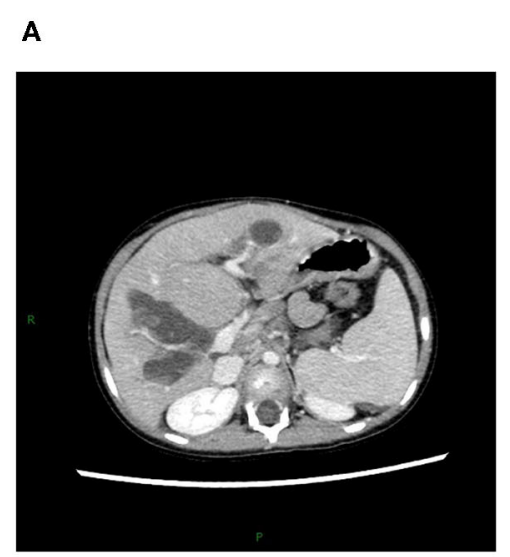

C

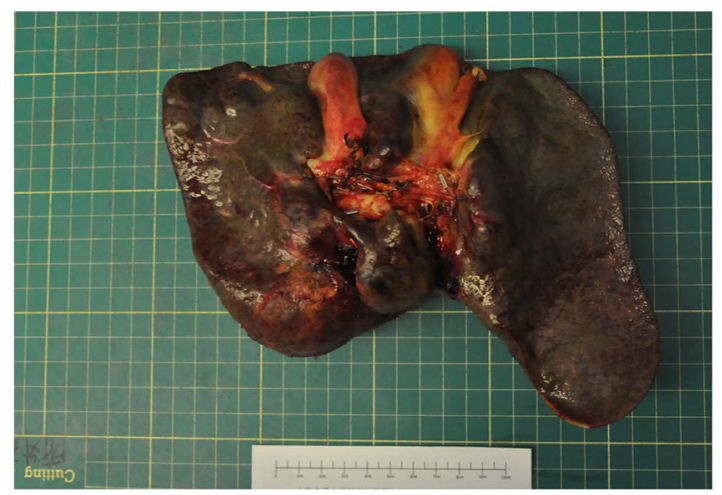

E

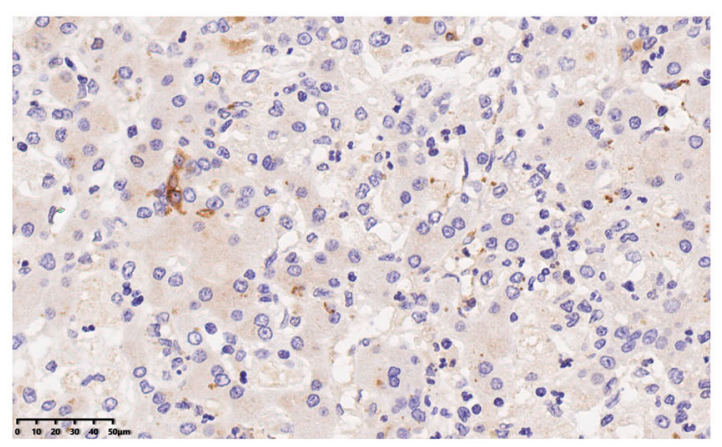

B

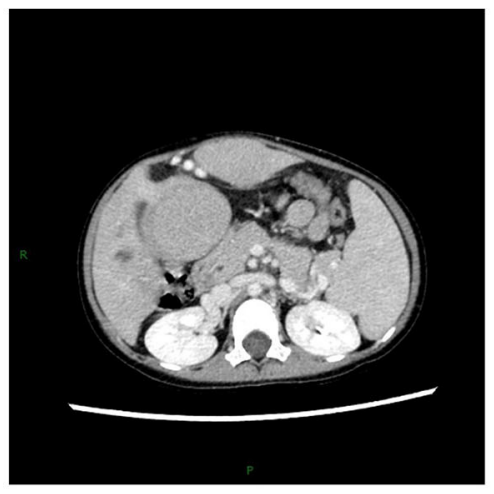

D

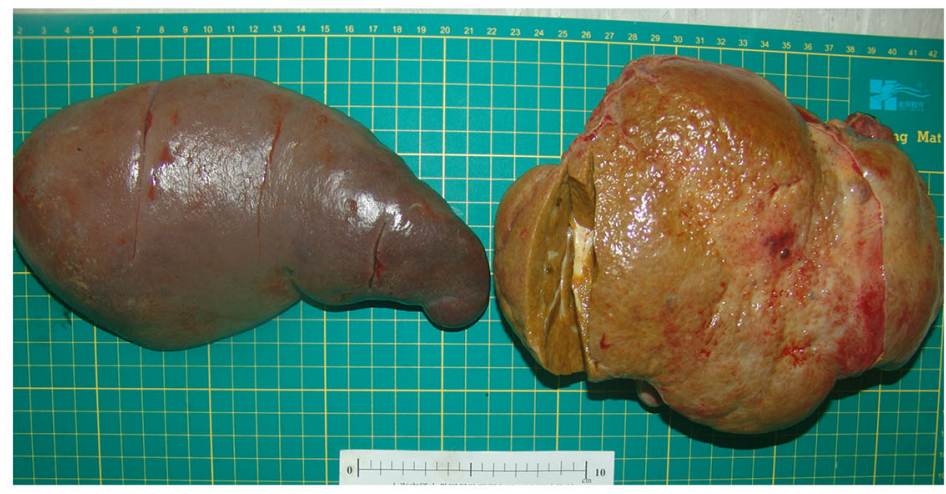

F

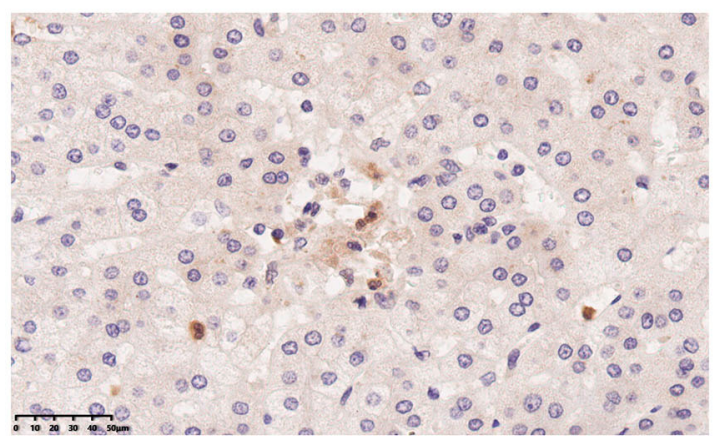

FIGURE 1 | Typical clinical presentations of LT children diagnosed with LCH. (A) CT scan revealing dilatation of intrahepatic bile duct, splenomegaly, hepatic mass lesions thought to be dysplastic nodules. (B) Varicose veins. (C) A 2-year-old patient's liver. (D) A 7-year-old patient's spleen and liver. (E) CD1a staining of liver, 40x. (F) Langerin staining of LCH patient's liver, $40 \times$.

counts postoperatively. There was no evidence of involvement of the urinary system, nervous system, skeleton, or mouth. No growth and development problems were found.

\section{DISCUSSION}

In this study, all five patients were multisystem childhood LCH, underwent chemotherapy prior to LT to improve preoperative status, including initial phase and maintenance phase. They all benefited from this paradigm with significant improvements of liver functions after LT. There were three underwent OLT and two underwent LDLT with left lateral lobe or left lobe with MHV graft. There were no serious vascular complications or recurrence of liver involvement. Four patients once had EBV infection and one patient had CMV infection. 2-67 months follow-up demonstrates that liver function has been stable without acute and chronic rejection. 


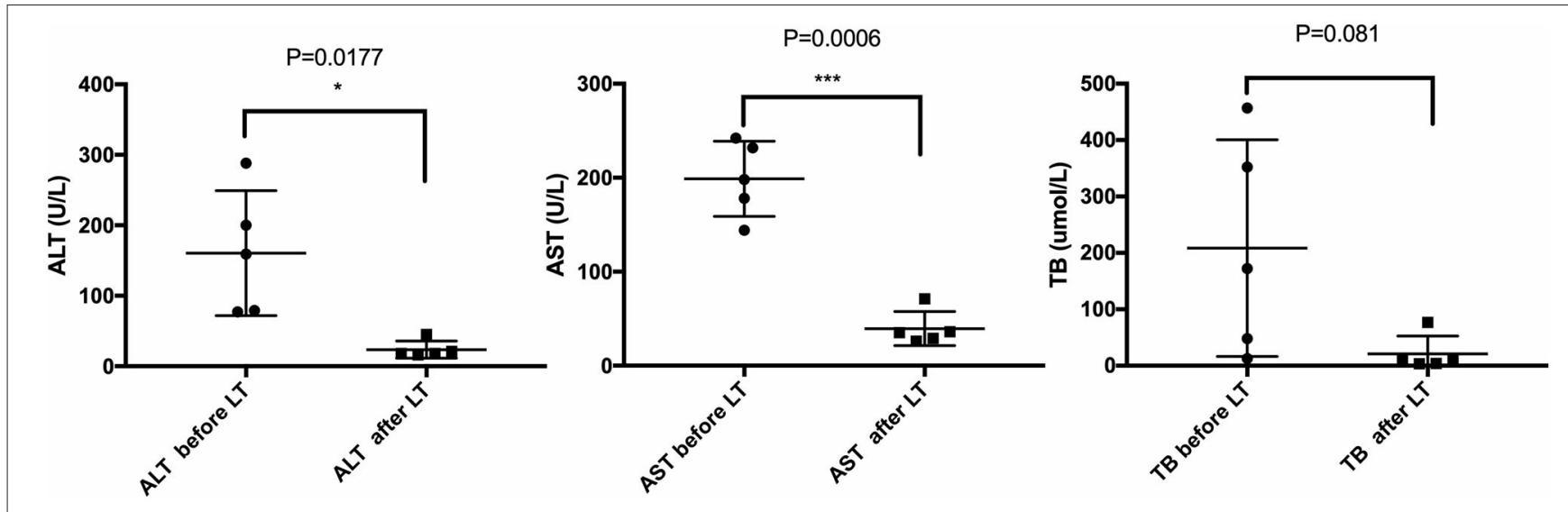

FIGURE 2 | Comparison of liver function before and after LT. Most recent follow-up data with the pre-operative liver function of LCH patients. ${ }^{\star} p<0.05 ;{ }^{\star \star *} p<0.001$. ALT, alanine transaminase; AST, aspartate transaminase; TB, total bilirubin.

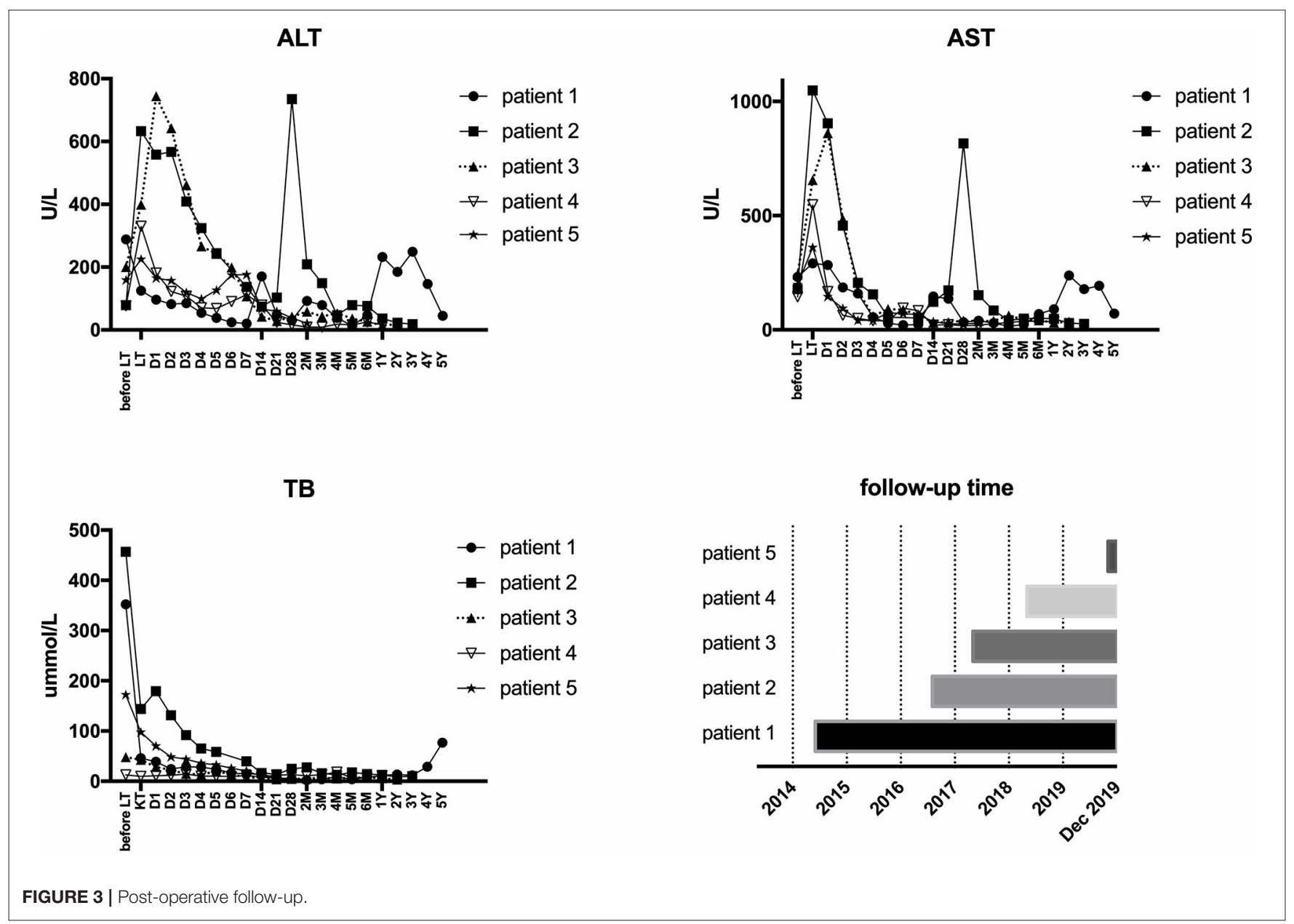

In our study, two LCH patients had sclerosing cholangitis before therapy, manifested as repeated attacks of fever and uneven beaded changes in left and right hepatic duct as well as common bile duct by radiology. Two patients underwent LT due to irreversible abnormalities of liver function, whose total bilirubin were 352.4 and $457 \mathrm{umol} / \mathrm{L}$ before LT. One patient had decompensated cirrhosis, manifested as variceal hemorrhage.

Our study has long follow-up pediatric patients with satisfactory outcomes and demonstrate that combination of neoadjuvant therapy and liver transplantation can cure liver 
TABLE 3 | Outcomes and complications of LCH patients after LT.

\begin{tabular}{|c|c|c|c|c|c|c|c|c|}
\hline $\begin{array}{l}\text { Patient } \\
\text { number }\end{array}$ & Status & $\begin{array}{l}\text { Immunosuppressive } \\
\text { drugs after LT }\end{array}$ & Rejection & Recurrence & $\begin{array}{l}\text { Drug-induced } \\
\text { injury }\end{array}$ & $\begin{array}{l}\text { Vascular } \\
\text { complications }\end{array}$ & Infections & $\begin{array}{c}\text { Follow-up } \\
\text { (months) }\end{array}$ \\
\hline 1 & Alive & TAC, MMF, rapamycin & No & Lung & Yes & $\begin{array}{l}\text { Hepatic artery } \\
\text { thrombosis }\end{array}$ & EBV & 67 \\
\hline 2 & Alive & TAC, MMF & No & No & No & None & No & 38 \\
\hline 3 & Alive & TAC & No & No & No & None & EBV & 29 \\
\hline 4 & Alive & TAC, MMF & No & No & No & None & EBV, CMV & 20 \\
\hline 5 & Alive & TAC & No & No & No & None & EBV & 2 \\
\hline
\end{tabular}

TABLE 4 | World report of pediatric LT for LCH patients.

\begin{tabular}{|c|c|c|c|c|c|c|c|c|c|c|}
\hline First author & Year & Country & $\begin{array}{l}\text { No. of } \\
\text { patients }\end{array}$ & $\begin{array}{l}\text { Mean age } \\
\text { at LT }\end{array}$ & Operation type & Status & Rejection & Recurrence & Complication & Follow-up \\
\hline Stieber (13) & 1990 & USA & $\begin{array}{l}2 \text { (exclude } \\
1 \text { adult) }\end{array}$ & / & OLT & Alive (100\%) & Yes (100\%) & No & $\begin{array}{l}\text { Uncontrollable rejection and } \\
\text { re-transplantations }\end{array}$ & $\begin{array}{l}57-60 \\
\text { months }\end{array}$ \\
\hline $\begin{array}{l}\text { Rand and } \\
\text { Whitington (14) }\end{array}$ & 1992 & USA & 2 & 4.25 y & $\begin{array}{l}\text { OLT } \\
\text { (reduced-size) }\end{array}$ & Alive (100\%) & Yes (100\%) & No & $\begin{array}{l}\text { Re-transplantation; CMV } \\
\text { infection and hepatitis; } \\
\text { gastrointestinal bleeding }\end{array}$ & $\begin{array}{l}\text { 30-34 } \\
\text { months }\end{array}$ \\
\hline Zandi et al. (15) & 1995 & France & 5 & $13 y$ & $\begin{array}{l}\text { OLT ( } 2 \text { whole } \\
\text { graft, } 3 \text { left liver) }\end{array}$ & Alive (60\%) & Yes (80\%) & No & $\begin{array}{l}\text { CMV infection; renal failure; } \\
\text { ulcer bleeding; multiorgan } \\
\text { failure }\end{array}$ & $\begin{array}{l}9 \text { days }-88 \\
\text { months }\end{array}$ \\
\hline $\begin{array}{l}\text { Melendez et al. } \\
\text { (16) }\end{array}$ & 1996 & UK & 1 & $2.5 y$ & OLT (right lobe) & Alive & Yes & No & $\begin{array}{l}\text { EBV-driven lymphoproliferative } \\
\text { disease }\end{array}$ & 19 months \\
\hline Newell et al. (17) & 1997 & USA & 6 & $3.1 \mathrm{y}$ & l & Alive (67\%) & Yes (100\%) & Yes (33\%) & $\begin{array}{l}\text { Re-transplantation (66\%); } \\
\text { PTLD }\end{array}$ & $\begin{array}{l}2.1-7.5 \\
\text { years }\end{array}$ \\
\hline Hadzic et al. (18) & 2000 & UK & 2 & 24 months & $\begin{array}{l}\text { OLT } \\
\text { (reduced-size) }\end{array}$ & Alive (100\%) & No & Yes (100\%) & PTLD & 5-60 months \\
\hline Braier et al. (19) & 2002 & Argentina & 5 & / & / & Alive (60\%) & Yes (20\%) & No & $\begin{array}{l}\text { Renal failure; sepsis; bowel } \\
\text { volvulus }\end{array}$ & $\begin{array}{l}\text { 14-37 } \\
\text { months }\end{array}$ \\
\hline Rajwal et al. (20) & 2003 & UK & 1 & 28 months & $\begin{array}{l}\text { SLT (left lateral } \\
\text { lobe) }\end{array}$ & Alive & Yes & Yes & PTLD & 16 months \\
\hline Honda et al. (21) & 2005 & Japan & 1 & 9 months & LDLT & Died & Yes & No & $\begin{array}{l}\text { EBV infection; CMV infection; } \\
\text { liver failure }\end{array}$ & 22 months \\
\hline $\begin{array}{l}\text { Yuksekkaya et al. } \\
\text { (22) }\end{array}$ & 2011 & Turkey & 1 & 28 months & LDLT & Died & Yes & No & GVHD; liver failure & 6 months \\
\hline
\end{tabular}

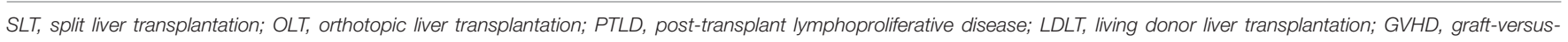
host disease.

failure episodes and relieve LCH by experienced surgeons. Hatemi et al. summarized isolated 13 case reports of LCH with sclerosing cholangitis in adults (12). LT for end-stage liver disease with LCH children has been reported for several cases (Table 4). Our outcomes were obviously better owing to surgical experience and skills in our center. In our series, three patients who underwent OLT and two who underwent LDLT all experienced remission postoperatively. This study pointed out the safety and efficiency of LT combined neoadjuvant chemotherapy in pediatric patients with multisystem LCH and liver involvement.

No standard therapeutic plan has been decided for $\mathrm{LCH}$ patients. Strategies include front line treatment and evaluation, maintenance therapy, salvage therapy (23). In the past, the most common therapy is vinblastine and corticosteroid for 612 weeks, tested by LCH-I, -II, and -III clinical trials (24-26). For patients exhibit involvement of risk organs, regimen of Ara$\mathrm{C}$, vincristine, and prednisolone is recommended by Japan $\mathrm{LCH}$
Study Group-96 (27). Targeted drugs such as vemurafenib has shown efficacy in LCH patients with BRAF-V600E mutation (28). In our study, four patients had good response status to initial phase and one case changed to second-line regimen. All of them had conditions for next step surgery after chemotherapy. On the other hand, liver transplantation cannot be performed unless chemotherapies control active lesions.

Among complications have been reported, post-LT infections and were more common than recurrence. In our study, four of the five became infected with EBV and one had CMV infection. One patient was diagnosed with recurrence of pulmonary Langerhans cell histiocytosis (PLCH). This recurrence was discovered on CT scan with typical signs of cystic lesions, that had also been present prior to LT. LCH may have an etiologic association with virus infection (22). The present study demonstrated that EBV DNA in LCH patients tissue samples was significantly greater than in control groups. Nineteen $(63.33 \%)$ 
of $30 \mathrm{LCH}$ patients had EBV DNA positive results (29). What's more, considering the admission of immunosuppressants, it is more likely for them infected with microorganisms. This suggests that the infection rate in our cohort is comparable to other studies. Nevertheless, we should remain vigilant for the development of EBV-associated diseases such as lymphoma (29). Regarding recurrence, after complete LCH resolution, the reactivation rate was $46 \%$ in 5 years in a retrospective analysis of 335 patients with multisystem LCH; (30) however, there were relatively fewer cases of recurrence in the liver. Hadzic et al. reported two patients with $\mathrm{LCH}$ who recurred in the grafts at 60 and 5 months after OLT (18). Although we believe that the possibility of liver recurrence is relatively low after remission, to improve outcomes in patients with multisystem disease, chemotherapy needs to be adjusted or prolonged (26).

Our study has some limitations. The number of enrolled patients is relatively small. Considering $\mathrm{LCH}$ is a rare disease, aggregating data is still needed to achieve a sufficient sample size to produce more reliable estimates, together with full documentation and multicenter cooperation.

In conclusion, according to our data, liver transplantation with neoadjuvant therapy is promising for $\mathrm{LCH}$ patients with end-stage liver disease. With advances in surgical techniques and pre-transplant management, we are more confident that LT will improve the outcomes for $\mathrm{LCH}$ children with liver involvement.

\section{DATA AVAILABILITY STATEMENT}

The raw data supporting the conclusions of this article will be made available by the authors, without undue reservation.

\section{REFERENCES}

1. Allen CE, Merad M, McClain KL. Langerhans-cell histiocytosis. N Engl J Med. (2018) 379:856-68. doi: 10.1056/NEJMra1607548

2. Krooks J, Minkov M, Weatherall AG. Langerhans cell histiocytosis in children: history, classification, pathobiology, clinical manifestations, and prognosis. $J$ Am Acad Dermatol. (2018) 78:1035-44. doi: 10.1016/j.jaad.2017.05.059

3. Berres M-L, Merad M, Allen CE. Progress in understanding the pathogenesis of Langerhans cell histiocytosis: back to histiocytosis X? Br J Haematol. (2015) 169:3-13. doi: 10.1111/bjh.13247

4. Broadbent V, Egeler RM, Nesbit ME, Jr. Langerhans cell histiocytosis-clinical and epidemiological aspects. Br J Cancer Suppl. (1994) 23:S11-6.

5. Labrune P, B\&lere HP, Clamart, Donadieu J, BaderMeunie B, Dommergues JP, et al. A multicentre retrospective survey of Langerhans' cell histiocytosis: 348 cases observed between 1983 and 1993. The French Langerhans' Cell Histiocytosis Study Group. Arch Dis Child. (1996) 75:17-24. doi: 10.1136/adc.75.1.17

6. Emile J-F, Abla O, Fraitag S, Horne A, Haroche J, Donadieu J, et al. Revised classification of histiocytoses and neoplasms of the macrophage-dendritic cell lineages. Blood. (2016) 127:2672-81. doi: 10.1182/blood-2016-01-690636

7. Minkov M. An update on the treatment of pediatric-onset langerhans cell histiocytosis through pharmacotherapy. Expert Opin Pharmacother. (2018) 19:233-42. doi: 10.1080/14656566.2018.1429405

8. Allen CE, Ladisch S, McClain KL. How i treat langerhans cell histiocytosis. Blood. (2015) 126:26-35. doi: 10.1182/blood-2014-12-569301

9. Tamefusa K, Ishida H, Washio K, Ishida T, Morita H, Shimada A. Remission of congenital multi-system type langerhans cell histiocytosis with chemotherapy. Acta medica Okayama. (2019) 73:61-5. doi: 10.18926/AMO/56459

\section{ETHICS STATEMENT}

The studies involving human participants were reviewed and approved by The Ethics Committee of Renji Hospital, School of Medicine, Shanghai Jiaotong University. Written informed consent to participate in this study was provided by the participants' legal guardian/next of kin. Written informed consent was obtained from the minor(s)' legal guardian/next of kin for the publication of any potentially identifiable images or data included in this article.

\section{AUTHOR CONTRIBUTIONS}

CC participated in data curation and analysis, as well as drafting the initial manuscript. GG and QX participated in research design and review or editing of the manuscript. TZ and $\mathrm{MH}$ provided resources of doing the investigation. All authors contributed to the article and approved the submitted version.

\section{FUNDING}

This work has received funding from National Natural Science Foundation of China (81700570).

\section{ACKNOWLEDGMENTS}

We gratefully recognize the willingness in this study by the family of the participating children and express our gratitude for their cooperation.
10. Morimoto A, Oh Y, Shioda Y, Kudo K, Imamura T. Recent advances in Langerhans cell histiocytosis. Pediatr Int. (2014) 56:451-61. doi: $10.1111 /$ ped.12380

11. Kelly DA. Current results and evolving indications for liver transplantation in children. J Pediatr Gastroenterol Nutr. (1998) 27:214-21. doi: 10.1097/00005176-199808000-00017

12. Hatemi I, Baysal B, Senturk H, Behzatoglu K, Bozkurt ER, Ozbay G. Adult Langerhans cell histiocytosis and sclerosing cholangitis: a case report and review of the literature. Hepatol Int. (2010) 4:6538. doi: 10.1007/s12072-010-9205-3

13. Stieber AC, Sever C, Starzl TE. Liver transplantation in patients with Langerhans' cell histiocytosis. Transplantation. (1990) 50:338-40.

14. Rand EB, Whitington PF. Successful orthotopic liver transplantation in two patients with liver failure due to sclerosing cholangitis with Langerhans cell histiocytosis. J Pediatr Gastroenterol Nutr. (1992) 15:202-7.

15. Zandi P, Panis Y, Debray D, Bernard O, Houssin D. Pediatric liver transplantation for Langerhans' cell histiocytosis. Hepatology. (1995) 21: 129-33.

16. Melendez HV, Dhawan A, Mieli-Vergani G, Rela M, Heaton ND, Pritchard J, et al. Liver transplantation for Langerhans' cell histiocytosis-a case report and literature review. Transplantation. (1996) 62:1167-71.

17. Newell KA, Alonso EM, Kelly SM, Rubin CM, Thistlethwaite JrJR, Whitington PF. Association between liver transplantation for Langerhans cell histiocytosis, rejection, and development of posttransplant lymphoproliferative disease in children. J Peiatr. (1997) 131:98-104.

18. Hadzic N, Pritchard J, Webb D, Portmann B, Heaton ND, Rela $\mathrm{M}$, et al. Recurrence of Langerhans cell histiocytosis in the 
graft after pediatric liver transplantation. Transplantation. 70:815-9. doi: 10.1097/00007890-200009150-00019

19. Braier J, Ciocca M, Latella A, de Davila MG, Drajer M, Imventarza O. Cholestasis, sclerosing cholangitis, and liver transplantation in Langerhans cell Histiocytosis. Med Pediatr Oncol. (2002) 38:178-182. doi: $10.1002 / \mathrm{mpo} .1306$

20. Rajwal SR, Stringer MD, Davison SM, Gerrard M, Glaser A, Tanner MS, et al. Use of basiliximab in pediatric liver transplantation for Langerhans cell histiocytosis. Pediatr Transpl. (2003) 7:247-51. doi: 10.1034/j.1399-3046.2003.00076.x

21. Honda R, Ohno Y, Iwasaki T, Okudaira S, Okada M, Kamitamari A, et al. Langerhans' cell histiocytosis after living donor liver transplantation: report of a case. Liver Transpl. (2005) 11:1435-38. doi: 10.1002/lt.20589

22. Yuksekkaya HA, Arikan C, Tumgor G, Aksoylar S, Kilic M, Aydogdu S. Late-onset graft-versus-host disease after pediatric living-related liver transplantation for Langerhans cell histiocytosis. Pediatr Transplant. (2011) 15:E105-E9. doi: 10.1111/j.1399-3046.2008.00899.x

23. Girschikofsky M, Arico M, Castillo D, Chu A, Doberauer C, Fichter J, et al. Management of adult patients with Langerhans cell histiocytosis: recommendations from an expert panel on behalf of Euro-Histio-Net. Orphanet J Rare Di. (2013) 8:72. doi: 10.1186/1750-1172-8-72

24. Gadner H, Grois N, Arico M, Broadbent V, Ceci A, Jakobson A, et al. A randomized trial of treatment for multisystem Langerhans' cell histiocytosis. J Pediatr. (2001) 138:728-34. doi: 10.1067/mpd.2001. 111331

25. Gadner $\mathrm{H}$, Grois $\mathrm{N}$, Pötschger $\mathrm{U}$, Minkov $\mathrm{M}$, Aricò $\mathrm{M}$, Braier $\mathrm{J}$, et al. Improved outcome in multisystem Langerhans cell histiocytosis is associated with therapy intensification. Blood. (2008) 111:2556-62. doi: 10.1182/blood-2007-08-106211
26. Gadner H, Minkov M, Grois N, Pötschger U, Thiem E, Aricò M, et al. Therapy prolongation improves outcome in multisystem Langerhans cell histiocytosis. Blood. (2013) 121:5006-14. doi: 10.1182/blood-2012-09-455774

27. Morimoto A, Ikushima S, Kinugawa N, Ishii E, Kohdera U, Sako M, et al. Improved outcome in the treatment of pediatric multifocal Langerhans cell histiocytosis: results from the japan langerhans cell histiocytosis study group96 protocol study. Cancer. (2006) 107:613-9. doi: 10.1002/cncr.21985

28. Kobayashi M, Tojo A. Langerhans cell histiocytosis in adults: advances in pathophysiology and treatment. Cancer Sci. (2018) 109:3707-13. doi: 10.1111/cas.13817

29. Panaite L, Shadman M. Concurrent diagnosis of classical Hodgkin lymphoma and Langerhans cell histiocytosis. Blood. (2019) 133:2109. doi: 10.1182/blood-2019-01-891937

30. Minkov M, Steiner M, Pötschger U, Aricò M, Braier J, Donadieu $\mathrm{J}$, et al. Reactivations in multisystem Langerhans cell histiocytosis: data of the international LCH registry. J Pediatr. (2008) 153:7005.e7052. doi: 10.1016/j.jpeds.2008.05.002

Conflict of Interest: The authors declare that the research was conducted in the absence of any commercial or financial relationships that could be construed as a potential conflict of interest.

Copyright (C) 2020 Chen, Gu, Zhou, Huang and Xia. This is an open-access article distributed under the terms of the Creative Commons Attribution License (CC BY). The use, distribution or reproduction in other forums is permitted, provided the original author(s) and the copyright owner(s) are credited and that the original publication in this journal is cited, in accordance with accepted academic practice. No use, distribution or reproduction is permitted which does not comply with these terms. 